\title{
SISTEMI UPRAVLJANJA OGNJENE PODPORE V SODOBNIH OBOROŽENIH SILAH
}

Povzetek Prizadevanje držav za zagotavljanje svetovnega miru je postala prednostna naloga. Trend združenega delovanja enot je vsesplošno prisoten in uveljavljen. Velik razkorak med zmožnostmi in resnično izvedbo združenega delovanja je privedel do tega, da so se začeli povezovati nacionalni sistemi poveljevanja in kontrole na ravni operativnega delovanja. Povezovanje sistemov zahteva predvsem standardizacijo postopkov in opreme, zato standardizacija ni več omejena le na nacionalno raven, temveč mora biti globalna.

Sodobni vojaški sistemi poveljevanja in kontrole so usmerjeni v optimalno reševanje nalog. Zgrajeni so mrežno, omogočajo vključevanje sedanjih in prihodnjih modulov ter komunicirajo med seboj brez dodatnih vmesnikov. S pravilnima usklajevanjem in delitvijo resursov pa precej zmanjšamo tudi materialna in finančna sredstva.

Ognjena podpora ima v nalogah zagotavljanja miru pomembno vlogo. Velika ognjena moč zagotavlja premoč na bojišču, saj ognjena podpora pomeni skupno in usklajeno uporabo ognjenega delovanja kopenskih, mornariških ter zračnih bojnih sistemov in delovanja ofenzivnih sistemov elektronskega bojevanja ter neubojnih sredstev na cilje na kopnem in morju.

Za zagotavljanje takšnega delovanja moramo imeti razvit ustrezen računalniški sistem, ki poveže vse komponente v sistem upravljanja ognjene podpore.

V potrditev pomembnosti ognjene podpore je v novejšem času prišlo do izvedbe računalniškega vmesnika, ki poveže sisteme upravljanja ognjene podpore posameznih držav v celoto in omogoča skupno delovanje. Vmesnik je izveden tako, da obdržimo nacionalne delovne procese. Tako se ni treba dodatno izobraževati in usposabljati. 
Slovenska vojska sledi globalizacijskim usmeritvam. Dokaz je nabava ustreznega operativnega in taktičnega sistema z možnostjo mednarodne povezave.

Žal nekateri sistemi Slovenske vojske nimajo te zmožnosti. Med njimi je sistem upravljanja ognjene podpore. Čeprav je sistem sodoben, brez ustrezne povezave tako v nacionalnem kot mednarodnem okolju izgublja veliko prednosti, zato se na tem področju iščejo nove, ustreznejše rešitve povezav, ki morajo izpolnjevati današnje in prihajajoče zahteve.

Prav tako lahko aplikacijo rešitve povzamemo tudi za druge avtonomne sisteme, kot je sistem za zagotavljanje obveščevalnih podatkov ali sistem vodenja logistike. Zavest, da nova standardizacija in mednarodna povezanost ne pomenita povečanja stroškov, temveč kakovostno izboljšanje delovanja in materialno zmanjšanje potrebnih sredstev, naj bo glavno vodilo.

Ključne besede

\section{Artilerija, ognjena podpora, globalizacija, sistemi poveljevanja.}

The effort of the countries to provide global peace has become a priority. The trend of combined unit operations is universally present and established. A large gap between the potential and actual execution of combined operations has led to the integration of national command and control (C2) systems at the operational level. The integration of systems primarily requires the standardization of procedures and equipment. The standardization is thus no longer limited solely to the national level, but it should be global.

Modern C2 systems are directed towards optimal completion of tasks. Built as networks, they allow for the integration of the existing and future modules and for their communication without additional interfaces. With a proper coordination and allocation of resources we also substantially reduce the material and financial resources.

Fire support plays an important role in providing security during peace tasks. At the same time, great fire power ensures battlefield superiority, since it includes joint and coordinated use of fire from land, navy and air engagement systems, and offensive operation of electronic warfare systems and non-lethal means against land and sea targets. Such operations require an appropriate computer system which links all the components into a fire support management system.

The awareness of the importance of fire support has led to the development of a computer interface, which connects fire support management systems of individual countries into a whole and thus enables joint operations. The interface was made in a way to preserve national work processes. Further education and training are therefore not necessary. 
The Slovenian Armed Forces (SAF) follows the globalization trends. To this end, it has acquired an operational and tactical system capable of international connections.

Unfortunately, some SAF systems, namely the fire support management system, do not include this feature. Although the system is a modern one, it loses a great deal of benefits due to the lack of appropriate national and international links. Therefore, new and more appropriate solutions for connections, capable of fulfilling contemporary and future requirements, are sought-after.

The application of the solution can also be applied to other autonomous systems, such as the intelligence system or the logistics management system. The main principle shall be the awareness that new standardization and international cooperation do not incur increased costs, but rather a quality improvement of the operations and a quantitative reduction of the required resources.

\section{Key words Artillery, fire support, globalization, command systems.}

Uvod Ognjena podpora pomeni združeno delovanje artilerijskih, minometnih, zračnih in mornarskih enot, torej vseh, ki z ognjem izvajajo bojne naloge v podporo bojnega delovanja. S svojim delovanjem zagotavljajo ognjeno moč, ki je najpomembnejši dejavnik za doseganje bojnih ciljev. Veliko ognjeno moč najlaže dosegamo z artilerijskimi sistemi ali natančneje sistemi ognjene podpore artilerijskih enot. Artilerijske sisteme vodimo prek sistemov upravljanja in vodenja ognja, ki predstavljajo celovite informacijske sisteme s povezanostjo po celotni hierarhiji in integracijo različnih modulov. Povezani so v nacionalne sisteme in so pomemben del združenih sistemov. Danes so posamezni nacionalni sistemi, v njihove podsisteme spadajo tudi sistemi upravljanja in vodenja ognja, zmožni opravljati zelo zahtevne naloge. Komunikacija poteka po vseh ravneh. Zgrajeni so mrežno, s svojo odprto arhitekturo pa omogočajo integracijo vedno novih, še sodobnejših rešitev.

Večnacionalna udeležba mirovnih misij je prinesla nove izzive. Tako kot se v pogovornem jeziku uporablja neki univerzalen jezik, se to pričakuje tudi v komunikaciji posameznih nacionalnih sistemov.

Velik razkorak med zmožnostmi in resnično izvedbo združenega delovanja je privedel do tega, da so se začeli povezovati nacionalni sistemi posameznih držav na ravni operativnega delovanja. Povezovanje je izvedeno z različnimi vmesniki, ki zagotavljajo nemoten pretok podatkov in skupno sliko. Sistemi ognjene podpore so zelo dobro povezani tudi na ravni taktičnega delovanja. Povezovanje sistemov zahteva predvsem standardizacijo postopkov in opreme, zato standardizacija ni več omejena le na nacionalno raven.

Globalizacijske smernice nam določajo prihodnje rešitve sistemov Slovenske vojske. Sistemi, kakršne ima danes Slovenska vojska, so z vidika potrebnih povezav 
neustrezni ali nepopolni. Sedanje stanje je treba nadgraditi tako, da bo rešitev pomenila odgovor na sedanje in prihodnje usmeritve. Za Slovensko vojsko tehnologija sistemov ni nekaj novega. Začetki uvajanja sistemov segajo že več kot desetletje nazaj. Sistem upravljanja in vodenja ognja artilerijskih enot (SUVO) štejemo za prvi pravi sistem Slovenske vojske (Jurtela, 2008). V nadaljnjih letih se je nabavilo še nekaj sistemov po posameznih področjih. Za vse sta bili značilni njihova avtonomnost in samozadostnost (Goričar, 2004).

S pridruževanjem Slovenske vojske Natu (North Atlantic Treaty Organization) in delovanju zunaj meja države so se pojavile potrebe po nabavi nacionalnega taktično operativnega sistema, ki bo kos nastalim potrebam. Lastnosti nabavljenega sistema odlično pokrivajo mednarodno interoperabilnost, pozabilo pa se je na svoje sisteme. Danes imamo operativni sistem, ki deluje mednarodno, vendar brez povezave $\mathrm{z}$ lastnimi podsistemi. Z nabavo bojnega sistema - battle management system (BMS) smo pokrili taktično raven operativnih enot. Tako je Slovenska vojska dobila sistem bojevnika 21. stoletja. Da bo ta lahko deloval suvereno in avtonomno na vseh zahtevanih področjih, bo potreboval celovito podporo (ognjena, logistika, obveščevalna dejavnost).

Ali lahko zagotovimo celovito ognjeno podporo s trenutnim sistemom v današnjem načinu bojevanja? Aplikacijo rešitve moramo povzeti tudi za druge avtonomne sisteme, kot je sistem za zagotavljanje obveščevalnih podatkov ali informacijski sistem logistike, ki je v nastajanju in prav tako brez možnosti povezave v sistem na operativni ali taktični ravni.

Rešitve, ki so v sodobnem svetu že stalna praksa, lahko Slovenska vojska večinoma povzame s pravilnim ovrednotenjem svojih potreb in sredstev.

Naj nas vodi zavest, da nova standardizacija in mednarodna povezanost ne pomenita povečanja stroškov, temveč kakovostno izboljšanje delovanja in količinsko zmanjšanje potrebnih sredstev.

\section{STRATEŠKI IN OPERATIVNO TAKTIČNI SISTEMI POVELJEVANJA IN KONTROLE}

Sestavo nekega sistema določa predvsem njegova namembnost. Od nalog, ki jih želimo reševati z njim, sta potem odvisni tudi njegovi velikost in konfiguracija. Današnji razvoj je usmerjen predvsem v modularnost sistemov, kar precej olajša načrtovanje in izvedbo. Povezovanje sistemov zahteva standardizacijo postopkov in opreme.

Če nacionalni sistem opredelimo kot sistem, ki ga uporablja posamezna država, se sistemi v oboroženih silah sveta v osnovi delijo na strateške in operativno taktične (Janes's, 2006). Razdelitev sistemov na strateške, operativne in taktične izhaja predvsem iz ravni odločanja. 
Združene države Amerike so kot najmočnejši svetovni predstavnik vsekakor primerne za prikaz tako strateških kot operativno taktičnih sistemov. Prikazali bomo tudi rešitev Nemčije kot zelo razvite evropske predstavnice in rešitve nekaterih drugih evropskih držav.

$\mathrm{Na}$ sliki 1 je prikazana osnovna zamisel povezave nacionalnih sistemov. Taka povezava zagotavlja poveljevanje in kontrolo po celotni hierarhiji. Vodilne predstavnice Nata večinoma sledijo tej osnovni zamisli. Razlikujejo se le glede na nacionalne značilnosti.

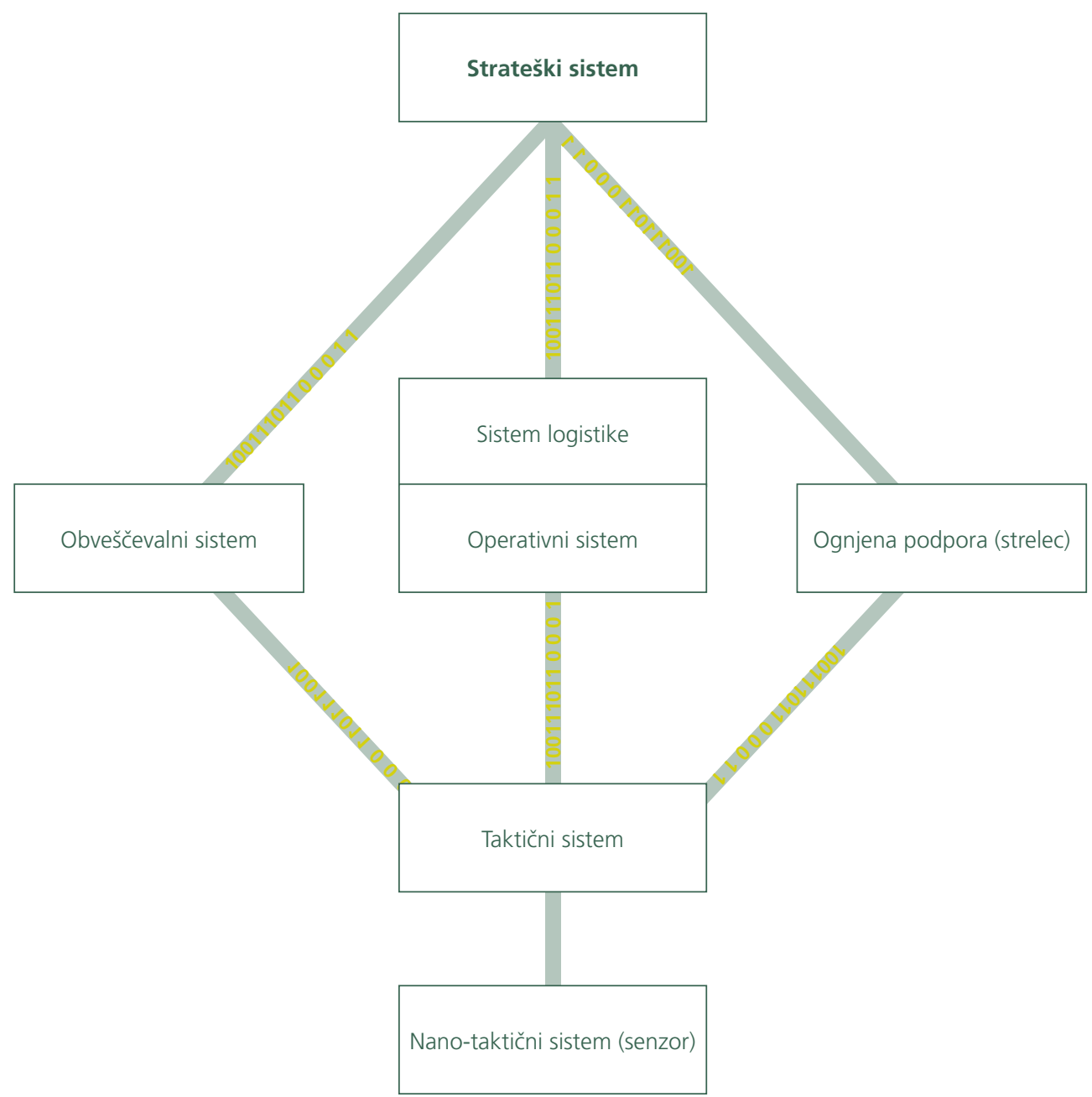




\subsection{Sistemi upravljanja ognjene podpore}

Ognjena podpora je ključen dejavnik pri doseganju bojnih ciljev, torej ključen element bojevanja. Tako je samoumevno, da dajejo oborožene sile posamezne države velik poudarek razvijanju in delovanju teh sistemov. Danes sta osnova teh sistemov avtomatizacija postopkov poveljevanja in kontrole ter horizontalna in vertikalna povezanost vseh delov. Zaradi združenega mednarodnega delovanja se je pokazala potreba po mednarodni povezavi sistemov, predvsem zaradi zagotavljanja nenehne ognjene podpore brez podvajanja resursov in z občutnim zmanjšanjem sredstev. Zato danes nastaja nova mednarodna povezava sistemov ognjene podpore, ki temelji na skupnih standardih. Imenuje se Artillery Systems Cooperation Activities (ASCA). Razvija se v vseh vodilnih članicah Nata.

\section{MEDNARODNI SISTEMII POVELJEVANJA IN KONTROLE}

\subsection{Strateški sistemi ZDA}

Na strateški ravni imajo oborožene sile ZDA več sistemov.

Najbolj znan je globalni poveljniško-informacijski sistem Global Command Control System Joint (GCCS-J), ki združuje sisteme kopenske vojske - Global Command Control SystemArmy A (GCCS-), mornarice - Global Command Control System Maritime (GCCS-M), letalstva - Global Command Control System - Air Force (GCCS-AF) ter marincev - Global Command Control System - Marine Corps (GCCS-MC) (Globalsecurity, 2009).

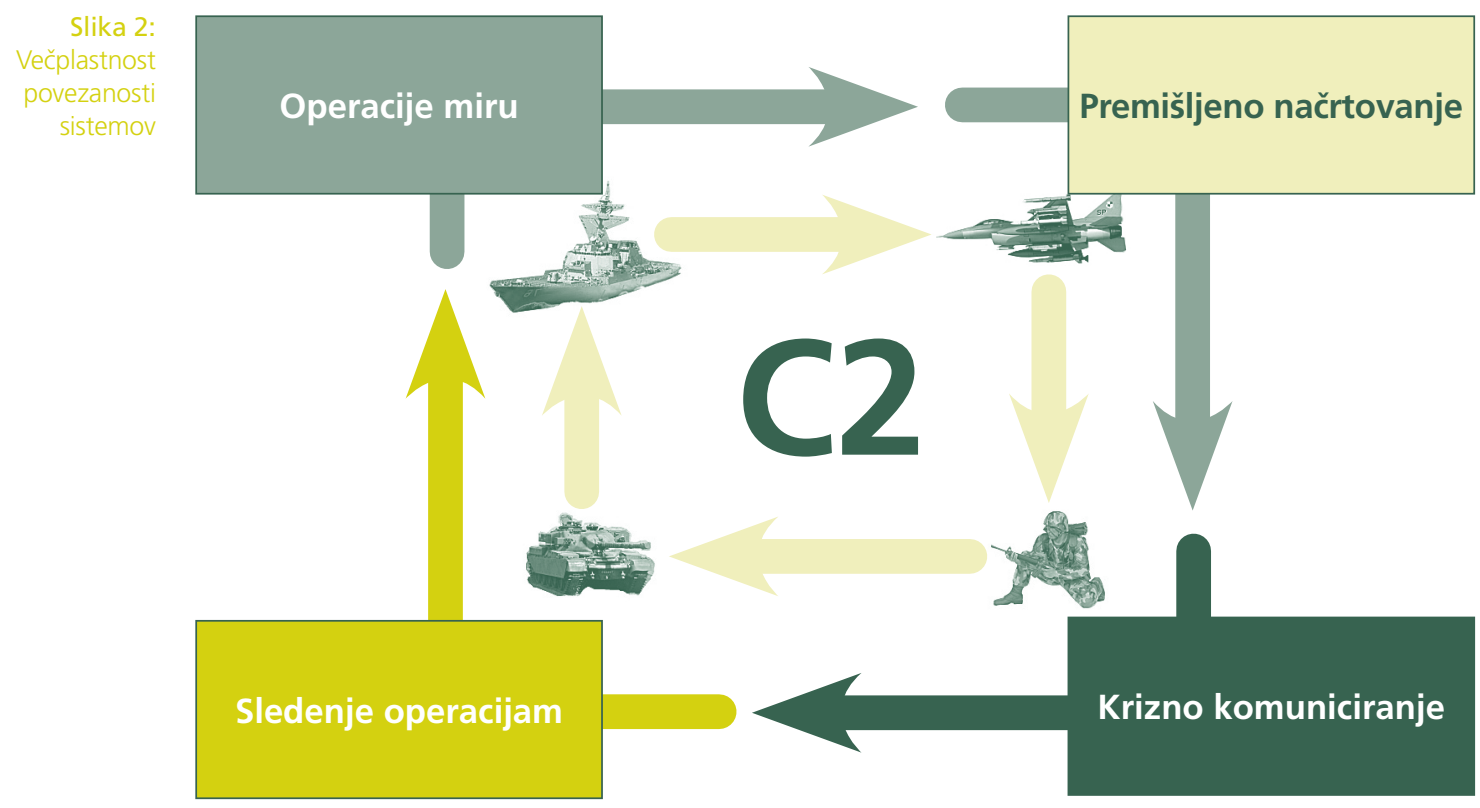


Poveljniško-informacijski sistem GCCS-J združuje strateške funkcije in funkcije bojišča ter podpira pripravo, načrtovanje in izvedbo, vključno s kriznim upravljanjem za mobilizacijo, z razvojem, angažiranostjo in podporo kopenskih sil. GCCS-J je avtomatizirani informacijski sistem, ki je bil razvit za podporo situacijske slike pri kriznem načrtovanju z uporabo združenih analitičnih orodij.

Slika 2 prikazuje kompleksnost sistemov. Posamezne zvrsti oboroženih sil (kopenska vojska, mornarica, letalstvo in marinci) so prek zaščitenega omrežja SECRET Internet Protocol Router Network (SIPRNET) povezane v združeni strateški globalni sistem ameriške vojske.

\subsubsection{Operativno-taktični sistemi v ZDA}

Glavni predstavnik operativno-taktičnega sistema je Army Battle Command System (ABCS), (U.S. Army Quarter Master Center and School, 2009), ki vsebuje veliko poveljniško informacijskih sistemov. V ABCS spadajo:

- strateški poveljniško-informacijski sistem kopenske vojske - Global command control system-Army (GCCS-A),

- taktični poveljniško-informacijski sistem - Army Tactical Command and Control System (ATCCS),

- sistem kontrole manevra - Maneuver Control System (MCS),

- taktični integrirani sistem nadzora zračnega prostora - The Tactical Airspace Integration System (TAIS),

- integrirani meteorološki sistem - The Integrated Meteorological System (IMETS),

- artilerijski taktični podatkovni sistem - Advanced field artillery tactical data System (AFATDS),

- zračna in raketna obramba - Air and Missile Defense Workstation (AMDWS),

- sistem za analizo vseh virov - All Source Analysis System (ASAS),

- sistem za bojno podporo delovanja - Combat Service Support Control System (CSSCS),

- sistem za digitalno topografsko podporo - Digital Topographic Support System (DTSS),

- sistem 21. stoletja za raven brigade in navzdol - Force XXI Battle Command Brigade and Below (FBCB2).

Za uspešno delovanje tako velikega sistema je potrebno veliko znanja, organizacijskih sposobnosti in komunikacijske discipline.

Operativno-taktični sistem kopenske vojske ABCS pomeni povezanost vseh ravni poveljevanja, kar se vidi na sliki 3.

Spremljamo lahko dogajanje v prvih bojnih vrstah do ravni korpusa. To je zelo pomemben dejavnik v današnjem načinu tako imenovanega razpršenega delovanja (Kočevar, 2008), saj lahko en na videz neznaten dogodek povzroči nepredvidene posledice. 
C2

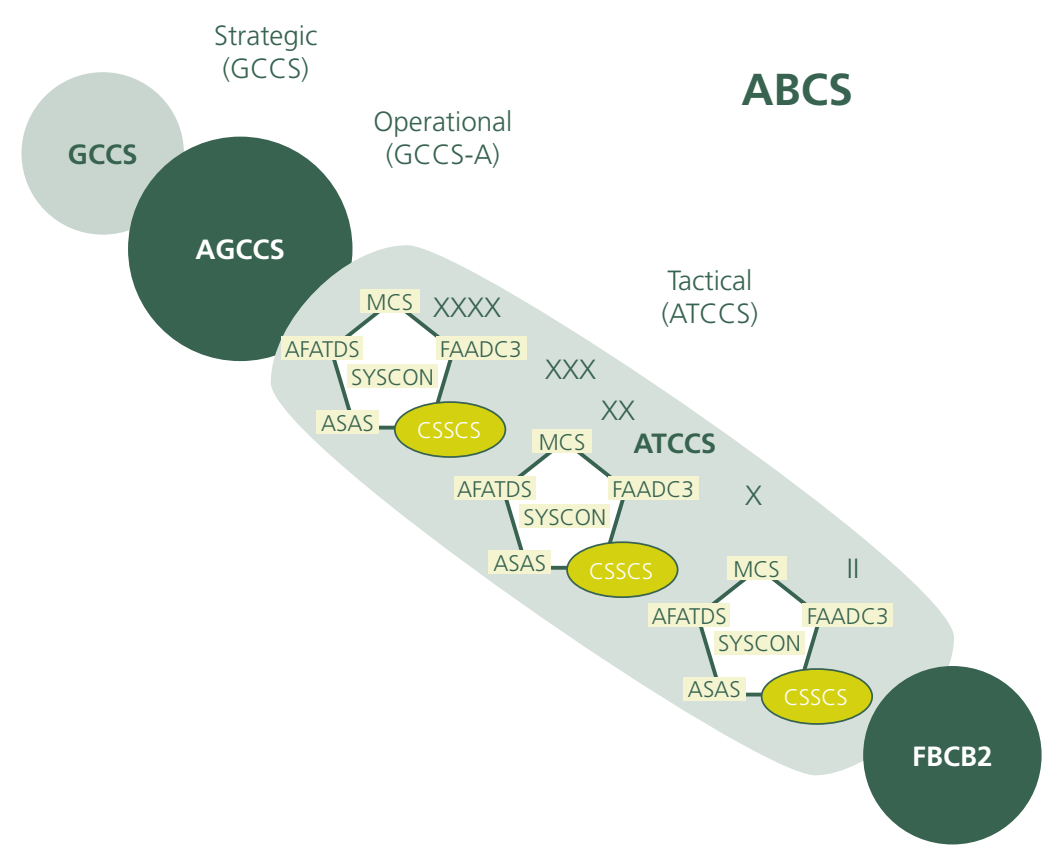

Zelo pomemben dejavnik je integracija vodenja in poveljevanja ter pritoka informacij različnih bojnih operacijskih sistemov. Združena slika danes predstavlja ključen element vodenja in poveljevanja.

\subsubsection{Sistem upravljanja ognjene podpore AFATDS (The Advanced Field Artillery Tactical Data System)}

AFATDS je sistem poveljevanja in kontrole, ki usklajuje naloge ognjene podpore in druge s tem povezane informacije. Omogoča optimizacijo uporabe vseh sistemov ognjene podpore, vključno z minometi, artilerijo, jurišnimi helikopterji, zračno podporo in podporo mornarice (Sailers, 2000).

Z uporabo razpoložljivih ognjenih sistemov, ki omogočajo izvedbo nalog z najmanjšimi mogočimi sredstvi v vsakem trenutku, obvladuje situacijo in optimizira potrebne in razpoložljive sile. Avtomatizacija procesov omogoča povečanje zmožnosti manevra in ognja. Med izvajanjem ognjenih nalog sproti zagotavlja informacije z bojišča, analizo ciljev in statuse enot. Hkrati prek senzorjev ocenjuje stopnjo nevtralizacije cilja in se ustrezno odzove. 
Vključevanje vseh sistemov ognjene podpore v en sistem kaže večjo stopnjo taktične mobilnosti in interoperabilnosti ter omogoča, da se naloge opravijo hitreje in učinkoviteje. AFATDS opravlja tudi druge naloge, kot so upravljanje kritičnih virov, zbiranje in posredovanje obveščevalnih podatkov, krmiljenje oskrbe, vzdrževanje in druge logistične funkcije. Zagotovljeni sta popolna strojna in programska povezanost, saj deluje na različnih strojnih platformah.

Danes se sistem uporablja v vseh enotah ZDA, od ognjenih vodov do mornariških sil. Prek sistema ASCA je povezan z drugimi sistemi ognjene podpore zavezniških sil, kot so angleški BATES, nemški ADLER II, francoski ATLAS in italijanski SIR. Sistem AFATDS so Portugalska, Turčija, Bahrajn in Egipt izbrale za svoj osnovni ognjeni sistem.

\subsection{Strateški sistem Nemčije}

$\mathrm{Na}$ strateški ravni nemška vojska uporablja poveljniško-informacijski sistem, imenovan Automatisiertes Korpsstammnetz (AUTOKO, 90). Sistem sestavljajo tranzitna in dostopna vozlišča, digitalne vozliščne centrale, radiorelejne postaje in linijski oddelki. Vmesniki omogočajo povezavo z digitalnimi omrežji, omrežji EUROCOM in s sistemom Breitbandiges Integriertes GefechtsSTAnd Fernmeldenetz (BIGSTAF), to je s poveljniškimi mesti brigad, divizij in korpusov (Jane's, 2008).

\subsubsection{Operativno-taktični sistem Nemčije}

V Nemčiji na operativno-taktični ravni uporabljajo sistem Command and Control and Information System HEROS (HEROS). Sistem HEROS je v celoti prilagojen kopenskim silam nemške vojske, na ravni korpusa, divizije in brigade (Armed Forces International, 2008).

HEROS je poveljniški, kontrolni in informacijski sistem, ki deluje kot ključni element za prenos podatkov. Z vmesniki pridejo do najbolj pomembnih nacionalnih in zavezniških sistemov prek standardov programa za doseganje multilateralne povezljivosti (MIP), ki so razviti za ta namen. Namen MIP je doseči povezanost nacionalnih sistemov poveljevanja in kontrole v mednarodnem okolju na vseh ravneh poveljevanja, od ravni korpusa do bataljona in nižje, vključujoč vse države članice Nata.

\subsubsection{Sistem upravljanja ognjene podpore ADLER II (Artillery, Data, Situation and Deployment Computer Network)}

ADLER II pomeni modularno-taktični sistem ognjene podpore, ki zagotavlja podporo v realnem času za vse enote na bojišču. Sestoji predvsem iz sistemov poveljevanja in kontrole, vseh trenutno razpoložljivih senzorjev ter sistemov za upravljanje in vodenje ognja.

Najpomembnejši značilnosti sta njegovi modularnost in možnost prilagajanja $\mathrm{v}$ različne sisteme sodelujočih enot. ADLER II temelji na izkušnjah, pridobljenih med 
dolgo fazo razvoja projektov, kot sta ADLER in DVA (Fischer, 2006). Sistem zagotavlja hitro in zanesljivo posredovanje podatkov vseh udeležencev na vseh izbranih ravneh. Prav tako je integriran mednarodni vmesnik ASCA, ki omogoča komunikacijo in sodelovanje v mednarodnem okolju.

\subsection{Francija}

Za Francijo je značilno, da se zanaša predvsem na svoje zmožnosti. Kot zagovornica vojaških sil EU daje poudarek predvsem sodelovanju z evropskimi državami. Od nedavnega je spet članica Nata (Adams, 2004).

Zagovarja prilagodljivost svojih oboroženih sil in izgradnjo različnih oborožitvenih sistemov.

\subsubsection{Sistem upravljanja ognjene podpore ATLAS (automated field artillery fire support system)}

ATLAS je najnovejša generacija sistema ognjene podpore, ki ga uporablja francoska vojska in je del programa digitalizacije bojišča (Jane's, 2009). Omogoča pridobivanje podatkov in opravljanje nalog v realnem času. ATLAS je zasnovan tako, da je zagotovljena popolna interoperabilnost z drugimi sistemi, udeleženimi v zagotavljanju ognjene podpore v operacijah miru (ASCA). Je naslednik sistema ATILA, ki ga je razvil Thomson-CSF (zdaj Thales). V operativni uporabi francoskih oboroženih sil je od leta 1980 in izvožen v približno ducat držav. Sistem zagotavlja podatke, potrebne za ognjeno podporo od strelca do brigade (cilji, pridobivanje sredstev, meteorološki podatki, kontrabatiranje), posreduje sporočila v mednarodni obliki, spremlja stanje v realnem času in optimizira ognjeno nalogo. Konfiguracija sistema je mrežno dinamična in zmožna prilagoditve operativnemu stanju enot. ATLAS uporabljajo tudi za minometne enote $120 \mathrm{~mm}$.

\subsection{Nizozemska}

Nizozemska ima veliko razvitih sistemov. Značilno je, da vse nove sisteme razvija skladno s STANAG-i. Za Slovensko vojsko je morda zanimivo, da uporablja sistem BMS, kakršnega uvaja tudi sama, in ima artilerijski sistem VUIST. Ta je od istega proizvajalca kot naš artilerijski sistem SUVO.

\subsubsection{Sistem upravljanja ognjene podpore VUIST}

Nizozemski sistem s simbolnim imenom VUIST (pest) je zanimiv predvsem zaradi dejstva, da je to predhodna različica slovenskega sistema SUVO (AFDVA, 2009). Nizozemci so imeli s sistemom VUIST precej težav pri uvajanju in so krepko zamujali z roki. Tako so medtem posegli tudi po predhodnem sistemu VUVA in ga uporabljali do uvedbe sistema v poznih devetdesetih letih. Od zamisli do uresničitve in uvedbe sistema je tako preteklo kar 26 let. Uvedba novega oborožitvenega sistema (PZH 2000) je povzročila nove potrebe. Tako Nizozemci zdaj uvajajo sistem Artillery Fire Support Information System-Battalion (AFSIS), ki bo zadovoljeval 
vse sodobne potrebe in omogočal vse sodobne zmožnosti delovanja. Tako naj bi sistem deloval prek sistema BMS. V sodelovanju z Nemčijo pa so skupaj razvili opazovalno vozilo FENEK.

\subsection{Italija}

Italija kot razmeroma razvita država zavzema majhen delež razvitih sistemov. Razen sodelovanja pri razvoju Evrofighterja nima lastnega razvoja. Zanaša se na nabavo sedanjih sistemov, pretežno izdelanih v ZDA. Po nabavi in uvajanju skladno $\mathrm{s}$ potrebami sprejema potrebno standardizacijo.

\subsubsection{Sistem upravljanja ognjene podpore SIR (Sistema Informatico Reggimentale) ali ATAFS (Artillery Tactical Automatic Fire System)}

SIR je taktični sistem ognjene podpore italijanske vojske. Sistem ravni baterije ali bataljona obsega vse glavne in pomožne funkcije, zahtevane za ognjeno podporo (Jane's, 2008). Prek Fire Direction Center (FDC) omogoča povezavo z vsemi drugimi enotami. Podatki obsegajo lastne sile in podatke o nasprotniku, varnosti in področju delovanja. Prav tako imamo podatke z meteorološke postaje, ki so pomembni za kakovost streljanja.

Omogočeni so povezanost $\mathrm{z}$ vsemi enotami v sistemu, avtomatsko sledenje in nadzor nad posredovanimi nalogami. Osnovna povezava je na ravni bataljona, baterije, orožja in opazovalca z nadrejenim poveljstvom. Glavne funkcije sistema so analiza ciljev, podpora načrtom ognja v realnem času, operativna in ažurna poročila stanja enot, stanja streliva, podatki o začetni hitrosti in meteorološki podatki, ki se samodejno obnavljajo, ter samodejni nadzor nad ognjem med enotami.

Z upoštevanjem Natovih standardov je prek ASCA omogočena povezanost z mednarodnimi sistemi ognjene podpore.

\subsection{Finska}

Morda bi omenili še sistem ognjene podpore, ki smo ga imeli priložnost spoznati. AHJO (Asianhallinnan järjestelmäkokonaisuus), sistem ognjene podpore finske vojske, je bil prikazan kot možna izbira sistema ognjene podpore za Slovensko vojsko. Je popolnoma avtomatiziran sistem finske vojske, ki so ga Finci razvili sami. Predstavitev je potekala v simulacijskem centru z dinamičnim prikazom. Globljega vpogleda v sistem finska vojska ni omogočila.

Iz prikaza lahko sklepamo, da je funkcionalno in organizacijsko zelo podoben drugim prikazanim sistemom. 


\section{ASCA (ARTILLERY SYSTEMS COOPERATION ACTIVITIES)}

ASCA je mednarodni standard, (ESG, 2008) ki predpisuje obliko in vsebino podatkov ter sporočil. V njem so povezani vsi največji sistemi ognjene podpore držav članic Nata. Cilj tega sodelovanja je usklajevanje operativnih zahtev in specifikacije vmesnika. Vsak posamezni sistem ASCA država samostojno uvaja, nato pa se skupaj testirajo. Najnovejša različica podpira načrtovanje, izvajanje in nadzor artilerijskega ognja. Standardni pogoji so definirani v različnih standardih in dokumentih.

Trenutno se izvaja testiranje že pete različice programa. Poudarek je na skupnih izvidniških senzorjih, kot so brezpilotna letala in radarji. Prav tako se izvaja testiranje pametnega streliva SMART.

Postopek izvajanja skupne naloge je načrtovan tako, da se prek nacionalnega taktično-operativnega centra sproži zahteva v nacionalni sistem ognjene podpore (Nemčija), ta pa prek ASCA posreduje zahtevo naprej v drugi nacionalni sistem ognjene podpore (ZDA), kjer se naloga naprej izvaja po nacionalnem ključu.
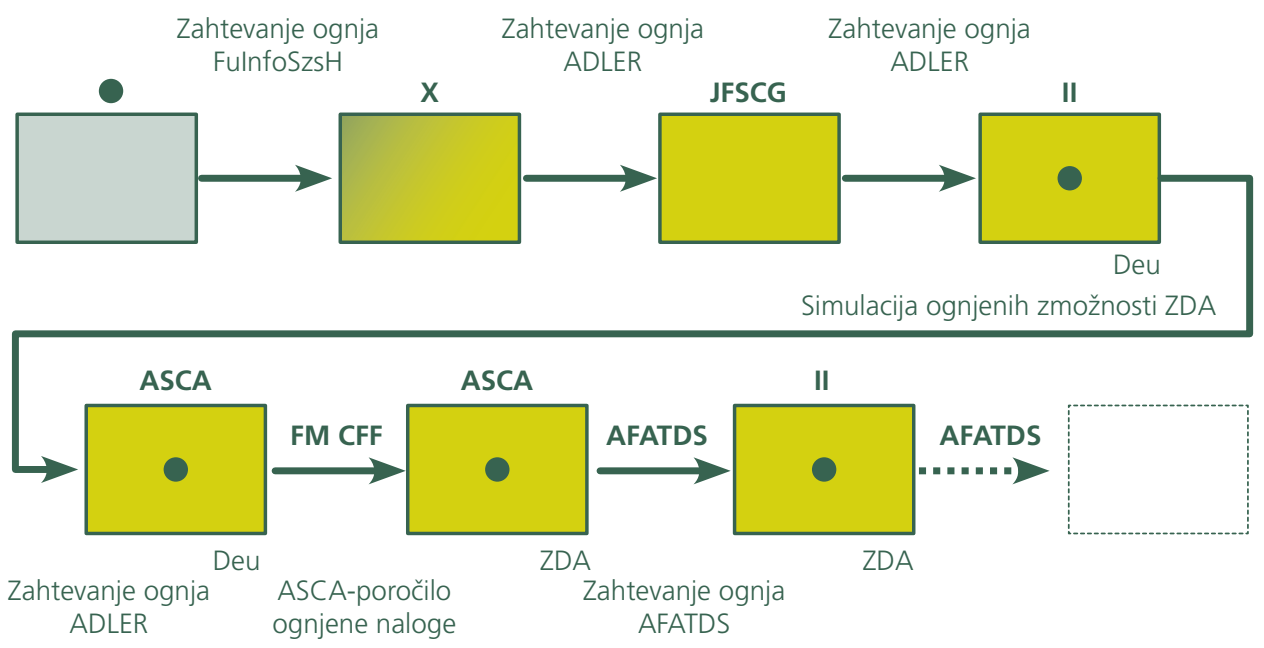

S sistemom ASCA ima artilerija že danes sposobnost vodenja, opazovanja in delovanja v večnacionalnih operacijah. Pri tem se sredstva za delovanje pri posameznih udeležencih ne spreminjajo. Trenutno se prek sistema ASCA zagotavlja ognjena podpora v Afganistanu, in sicer jo zagotavljajo enote ameriških in nemških sil.

S pravilnim usklajevanjem in delitvijo teh sredstev je mogoče v veliki meri tudi zmanjšati tako materialna kot finančna sredstva. 
Tako s skupno taktično uporabo ognja v sistemu ASCA udeležene vojske niso sposobne samo nacionalnih bojnih operacij, temveč lahko večnacionalno povezani bojno delujejo.

To je mogoče brez dodatnih časovnih in tudi denarnih vložkov za osebje ali izobraževanje, saj lahko brez posebnih dodatnih izobraževanj obdrži nacionalne delovne procese.

\section{SISTEMI POVELJEVANJA IN KONTROLE SLOVENSKE VOJSKE TER} NJIHOVA MEDNARODNA POVEZLJIVOST

Slovenska vojska v okviru svojih zmožnosti sledi razvoju na področju sistemov upravljanja. Kot majhna, sodobno opremljena vojska se je zelo zgodaj začela zavedati potrebe uvajanja takšnih sistemov v operativno uporabo. Zaradi kratke zgodovine Slovenske vojske se ne uporabljajo starejši primerki, temveč se nabavljajo novi sodobni sistemi z vsemi lastnostmi, ki jih zahteva sodoben način bojevanja. Osnova so povezanost navzven, horizontalna in vertikalna komunikacija ter mrežno delovanje. Prav tako je treba omogočiti priključitev tako domačih kot tujih senzorjev, odvisno od trenutne potrebe. Vsekakor so v Slovenski vojski takšne potrebe spoznane kot podlaga, na kateri se bo gradilo naprej, skladno s potrebami in zmožnostmi.

Slovenska vojska na strateški ravni nima sistema. Takšna zasnova ne pomeni primanjkljaja, saj zaradi svoje majhnosti trenutno še ni velikih potreb po takšnem sistemu, kar pa se lahko zelo hitro spremeni. V današnjem času vsaka kaotična situacija na kriznem žarišču zahteva takojšnje seznanjanje in odziv odgovornih prav na vrhu.

Kot ugotavljajo (Prezelj, 2003), je podlaga za tak sistem že zgrajena z ustreznim taktičnim telekomunikacijskim sistemom (TTKS), ki lahko pokriva komunikacijske potrebe od najvišjega poveljstva pa do posameznika na terenu. Omenjeni komunikacijski sistem s seboj prinaša tudi zmožnosti, ki jih do zdaj ni bilo, in so vezane na vzpostavitev podatkovnih tokov.

Na operativni ravni je v Slovenski vojski prvič v uporabi informacijski sistem poveljevanja in kontrole (IS PINK) od ravni brigade navzdol. Namen IS PINK-a je po eni strani vezan na dvig bojne pripravljenosti (učinkovitosti poveljevanja in kontrole) enot Slovenske vojske, po drugi strani pa na zadovoljevanje novonastalih potreb kot posledica priključevanja zvezi Nato in na delovanje Slovenske vojske v mirovnih operacijah zunaj ozemlja Slovenije (Systematic, 2007).

Učinkovitost procesov poveljevanja in kontrole je neposredno povezana s predstavo bojišča, ki jo ima poveljnik ob sprejemanju svojih odločitev. Naloga sistema IS PINK je zagotoviti kritične in pravilne informacije tam in takrat, ko so potrebne. $\mathrm{Ob}$ tem se je treba zavedati, da je to le prvi korak na poti k celovitemu sistemu. Danes so osnove vsakega sodobnega sistema združena slika, predstavljena v realnem času, dojemanje bojišča, zmožnost poveljevanja in odzivanja na situacijo tako vertikalne kot horizontalne koordinacije, nujne za normalno delovanje, ter tekoč proces in povezovanje brez nepotrebnih vmesnikov z drugimi udeleženci na vseh ravneh. 
Osnovne značilnosti in pomen sistema IS PINK se kažejo v skrajšanju odzivnih časov in povečanju tempa delovanja. Vse smernice sodobnega bojevanja se gibljejo v smeri sprejemanja hitrih odločitev in povečanja angažiranja enot.

Na taktični ravni je izvedena povezava IS PINK z aktivnimi enotami na terenu prek sistema BMS, ki je trenutno v fazi preizkušanja (Systematic, 2008).

Predstavlja integracijo sistema na ravni vozila s povezavo prek LAN-a (komunikacijska, računalniška oprema, senzorji, strelci) in omogoča:

- glas po celotni liniji poveljevanja in kontrole,

- izmenjavo podatkov po celotni liniji poveljevanja in kontrole,

- povezanost z IS PINK-om višje ravni,

- interoperabilnost z Natom (Natovi in MIP-standardi),
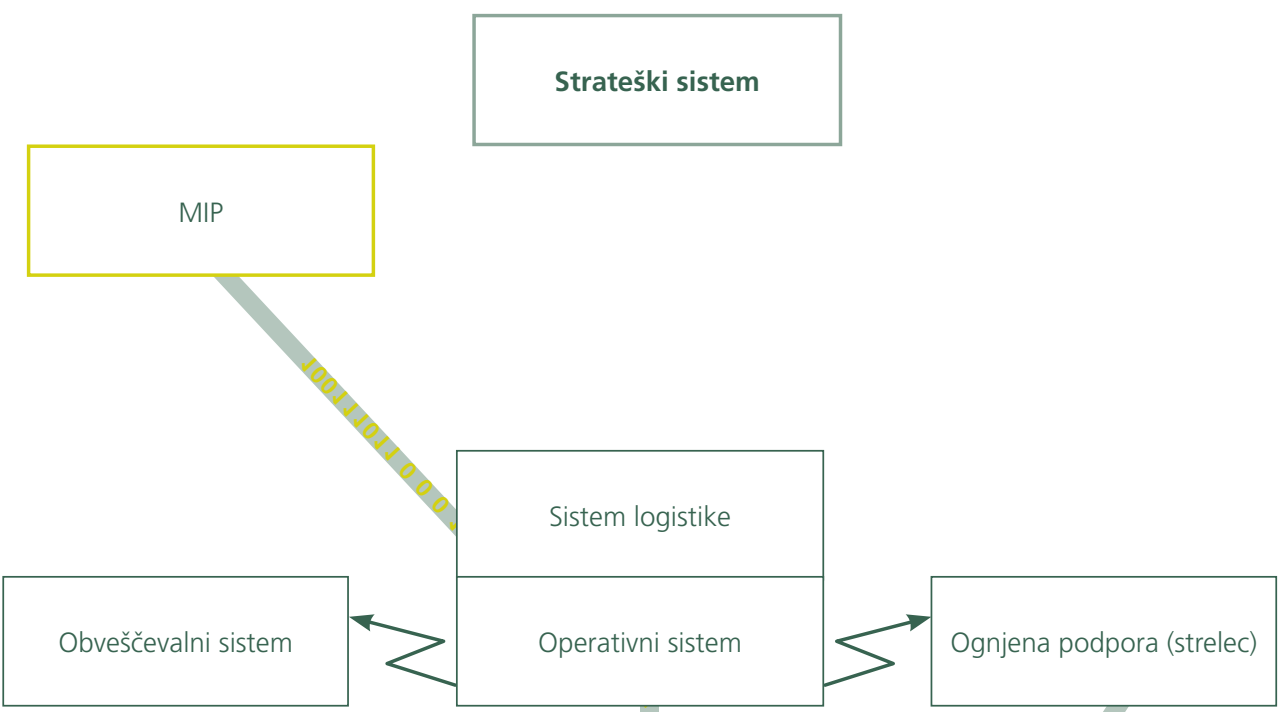

Taktični sistem 
Z zgoraj opisanim projektom je Slovenska vojska prvič stopila na pot informacijsko podprtega poveljevanja in kontrole. Sistem, ki ga uporabljamo, predstavlja le ogrodje za razvoj v naslednjih letih. Naloge, ki s tem prihajajo, so obsežne in vezane predvsem na integracijo vseh vojaških sistemov:

- vključitev trenutnih sistemov (ISTAR, SUVO),

- vključitev sistemov v nastajanju (ISLOG - informacijski sistem logistike),

- pokritje funkcijskih področij (RKBO, ZO, inženirstvo ...).

Sistem IS PINK je popolnoma primerljiv s podobnimi operativnimi sistemi v svetu. Izveden je tako, da omogoča povezavo z drugimi sodelujočimi državami brez dodatnih vmesnikov. Programska izvedba baze je v osnovi enaka, kot jo uporabljamo v povezavah MIP.

Kot zanimivost lahko tukaj omenimo rešitev Velike Britanije, ki je sistem Sitaware prav zaradi MIP-a kupila za delovanje na misijah, medtem ko v domovini uporablja drug sistem. Na sliki 5 je prikazano sedanje stanje, ki ponazarja predvsem nepovezanost lastnih sistemov, in stanje, ki bi ga bilo treba doseči.

\subsection{Sistem upravljanja artilerijskega ognja (SUVO)}

Sistem za upravljanje in vodenje artilerijskega ognja (SUVO) je opredeljen kot artilerijski sistem bataljonske ravni (Jurtela, 2008).

Namenjen je zagotavljanju podpore ognjenim nalogam artilerijskega bataljona.

Glavne naloge sistema:

- zbiranje, razvrščanje in upravljanje nujnih podatkov,

- upravljanje bojnih operativnih enot,

- taktični in tehnični nadzor nad ognjem v vseh nalogah,

- jasna in sprotna informacija o vseh geografskih podatkih na delovni karti.

V času nabave sistema SUVO se je Slovenska vojska oboroževala z visoko zmogljivim artilerijskim orožjem in v duhu nabave se je kupoval ustrezen sistem. Sistem SUVO je s svojimi funkcijami tudi danes, deset let od nabave, še popolnoma konkurenčen sodobnim sistemom. Uporabna vrednost se dokazuje na številnih vajah in streljanjih. Takrat zelo sodobne rešitve so danes standard znotraj sistemov ognjene podpore. Uporabnost tega sistema pa je kljub sodobni zasnovi omejena na delovanje znotraj bataljona.

Brez povezave z lastnim taktičnim sistemom tako sistem izgubi obilico prednosti, ki so bile naštete na začetku in veljajo tako za sistem upravljanja ognjene podpore kot druge sisteme. 


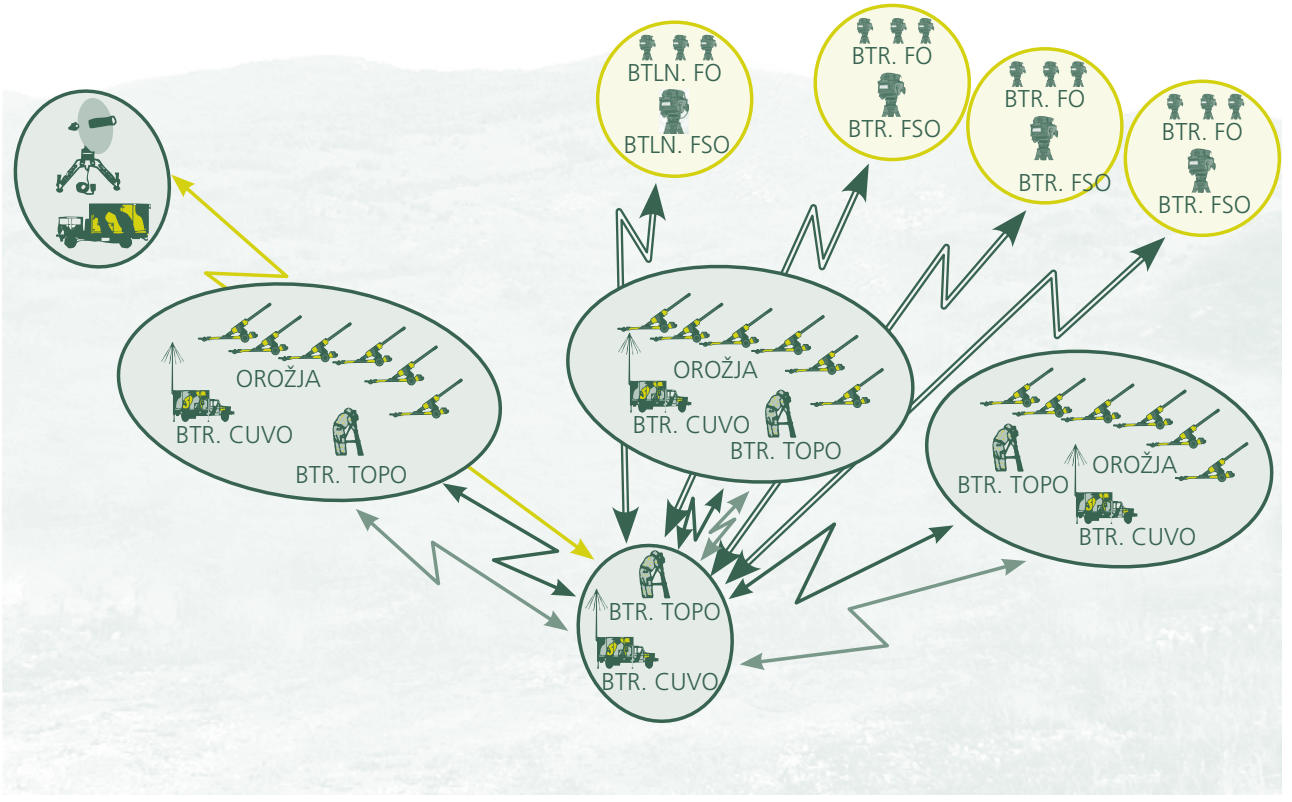

Sklep Ognjena podpora je ključen dejavnik bojnega delovanja. V povezavi z najsodobnejšo računalniško tehniko danes takšne enote pomenijo veliko ognjeno moč in avtonomnost delovanja. Za operativno doseganje zmožnosti delovanja pa je nujno usklajevanje z drugimi udeleženci. Danes je velika večina nacionalnih sistemov poveljevanja in kontrole izvedena tako, da omogoča izvajanje najrazličnejših nalog, pred katere jih postavljajo nastali izzivi. Tudi širša povezanost teh sistemov z drugimi državami je postala že standard, ki se ga zavedajo in ga uresničujejo.

Naloge vojske so danes usmerjene v podporo miru po svetu. V njih redko ali nikoli ne sodelujejo samostojno, temveč v sodelovanju s članicami Nata.

Operacije, pri katerih vojske različnih držav z različnimi rodovi delujejo skupaj, zahtevajo celosten pristop in sodelovanje. Cilj sta usklajevanje vseh zmogljivosti udeleženih sil in izvedba v smislu učinkovitega doseganja postavljenega cilja.

V ospredju je sposobnost vojske kot celote in ne sposobnost posameznega organizacijskega področja. Najsodobnejši sistemi ognjene podpore so danes zmožni to nalogo opraviti avtonomno, brez posredovanja in nepotrebnega izgubljanja najpomembnejše komponente, časa. Rešitev je hiter in varen prenos podatkov med posameznimi delnimi sistemi prek vseh relevantnih sistemov odločanja.

Dobra rešitev je sistem ASCA, ki nam omogoča skupno delovanje ognjene podpore na taktični ravni. Nenehne izboljšave sistema in nove rešitve pa nam odpirajo nove možnosti uporabe. Šesta in sedma generacija vmesnika predvidevata nove zmožnosti 
uporabe. Tako bo informacija, pridobljena na ravni senzorja, avtomatsko prevzeta in obdelana. Glede na zahtevano nalogo (prioritete in nujnost) se bo ustrezno aktivirala enota, primerna za doseganje tega cilja. Posredovano nalogo bodo letalstvo, pomorstvo in pehota mednarodnih sil ustrezno usklajevali. Vse skupaj pa bo ustrezno logistično podprto.

Ob dejstvu, da za povezovanje v tak sistem ne potrebujemo dodatnih sredstev, temveč le ustrezno programsko opremo, se zdi dana rešitev zelo ustrezna. Še posebno ob zavedanju, da lahko s takim sistemom delno koristimo zmožnosti drugih držav ali jih sami ponujamo. Za primer navedimo skupno sliko bojišča ali pridobivanje meteoroloških podatkov. Idealna za naloge zagotavljanja miru je rešitev, prikazana na sliki 7 , ki nam omogoča nemoteno večnacionalno delovanje z delitvijo sredstev. Vsak udeleženec se prek svojega sistema priključi na skupni vmesnik.

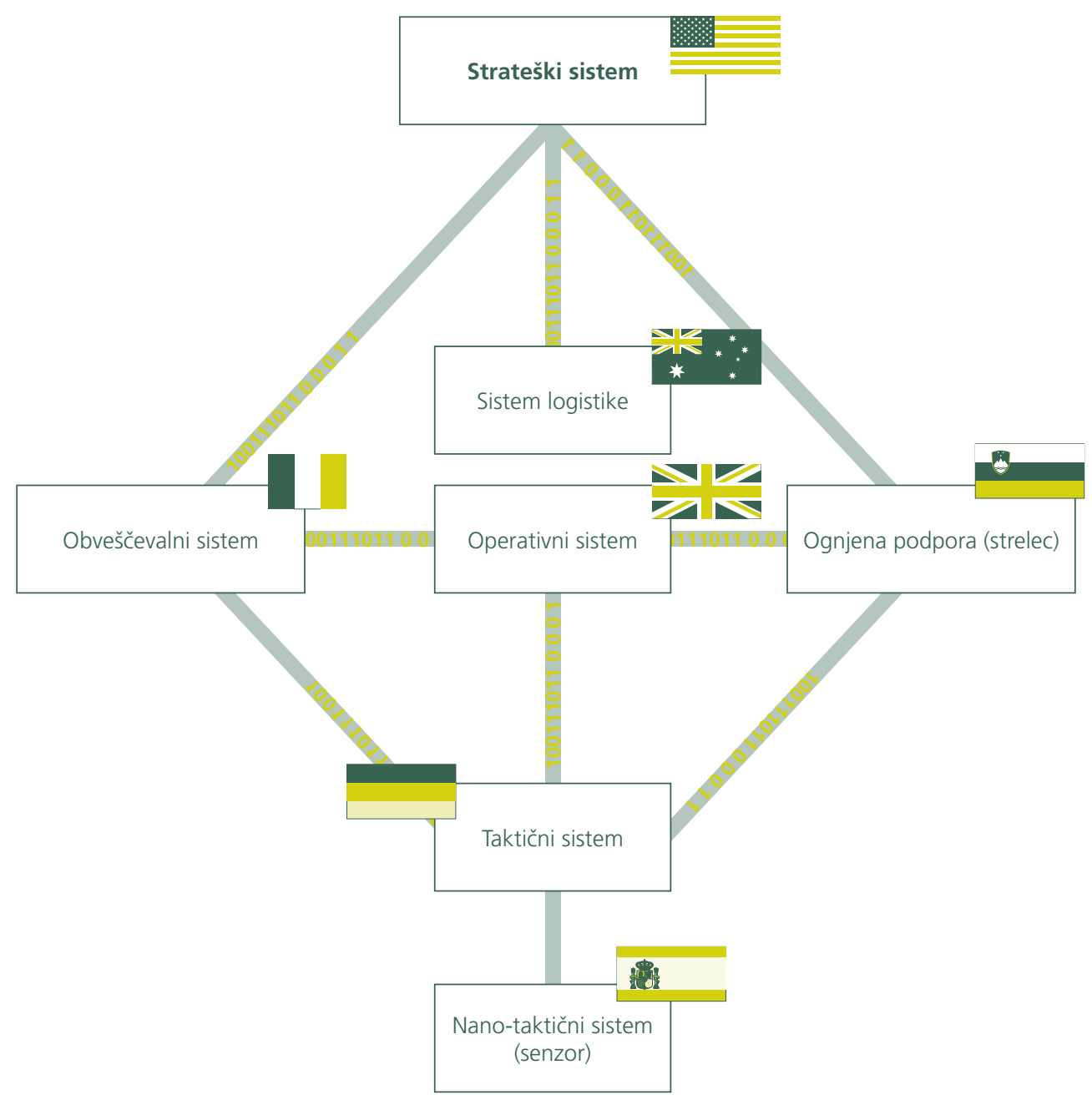


Zadanim ciljem Slovenske vojske o majhni, visoko zmogljivi vojski je najlažje slediti s povzemanjem ali sledenjem rešitev velikih vojsk in razumnim prilagajanjem na raven potreb svojih sil.

Nacionalni operativno-taktični sistem ob vseh opisanih lastnostih v veliki meri sledi sodobnim smernicam v svetu. Mednarodna povezanost danes pomeni standard, ki smo se ga vsi začeli dobro zavedati.

Načrtovane nadgradnje (BMS, Nano BMS) z ustreznimi podsistemi bodo precej povečale operativnost tega sistema. Z odprto arhitekturo BMS pa imamo možnosti povezave drugih ustreznih sistemov, kot je sistem ognjene podpore, pri čemer Slovenska vojska še išče rešitev za ustreznost nabave novega sistema. Vsekakor morajo biti dosedanja spoznanja o pomembnosti povezav in globalizacijske smernice osnovno vodilo. Predvsem zaradi dejstva, da nam taka rešitev omogoča tako zmanjšanje resursov kot finančnih sredstev.

Čeprav sedanji sistem SUVO po desetletju uporabe ne deluje kot izrabljen in zastarel ter so njegove operativne funkcije povsem na ravni najsodobnejših, je vprašanje zagotovitve celovite ognjene podpore povsem primerno. Nezmožnost povezave v celovit sistem poveljevanja in kontrole nam omeji delovanje sistema na ravni bataljona. Glede na dosedanje ugotovitve pomembnosti povezav in skupnega delovanja lahko trdimo, da sedanji sistem ne zagotavlja teh zahtev. Zaradi precejšnje starosti sistema pa je vprašljiva tudi možnost nadgradenj oziroma posodobitev. Nekaj dobrih rešitev glede sistema lahko iščemo v možnostih šolske uporabe ali uporabe posameznih komponent (meteorologija, opazovalni moduli). Ta sredstva se lahko uporabijo tudi pri novih sistemih.

Ob nabavi novih ognjenih sistemov, ki bodo upravičeno zagotavljali veliko ognjeno moč, lahko pričakujemo sistem upravljanja in vodenja ognja, ki bo ustrezal potrebam sodobnega časa, s povezavo prek ASCA z drugimi državami, in hkrati zagotavljal povezanost $\mathrm{z}$ nacionalnim sistemom.

Prednostna naloga Slovenske vojske, ki izhaja iz teh spoznanj, je ob dejstvu, da smo s sedanjim sistemom že pridobili veliko izkušenj o delovanju sistemov, zagotovitev sodelovanja v organizaciji ASCA. Z aktivnim delovanjem v ASCA bomo prišli do optimalne rešitve sistema zagotovitve upravljanja ognjene podpore, ki bo ustrezal vsem zahtevam sodobnega časa. Ustrezal bo sedanjim in prihodnjim potrebam. S smotrnim in odgovornim povezovanjem pa bomo zmanjšali tako materialna kot finančna sredstva.

Danes nabava takega sistema zahteva velika finančna sredstva, ki se z minimalnimi naročili žal samo povečujejo, hkrati pa se zmanjšujejo tudi pogajalske zmožnosti. Dobra rešitev je najem ustreznega sistema za posamezno nalogo. Tako rešitev uporablja kar nekaj držav v okviru mednarodnega sodelovanja. 
Na trgu je veliko zelo dobrih razvijalcev sistemov. Proizvajalci sledijo najnovejšim usmeritvam in programske rešitve že vsebujejo najsodobnejše rešitve, kot je integracija vmesnika ASCA.

Ob spoznanju in definiranju potreb smotrnost nabave takega sistema nikoli ne sme biti vprašanje.

1. Adams, G., Ben-Ari, G., Logsdon, J., Williamson, R., 2004. Bridging the Gap - European C4ISR Capabilities and Translantic interoperabilit. Washington DC: Center for Strategic and International Studies.

2. Fischer, H., 2006. Artillerieschule Idar-Oberstein. Infomape: Idar-Oberstein.

3. Globalsecurity, 2009. Force XXI Battle Command, Brigade-and-Below (FBCB2). http:// www.globalsecurity.org/military/systems/groud/fbcb2.htm, 19. 2. 2011.

4. Goričar, M., 2004. Operativno taktični sistemi C4I. Bilten Slovenske vojske, december 2004 - 6(1). Ljubljana: GŠSV, str. 105-136.

5. Jurtela, J., 2008. Navodilo za uporabo sistema za upravljanje in vodenje ognja-baterija. Ljubljana: Poveljstvo za doktrino razvoj izobraževanje in usposabljanje.

6. Kočevar, I., 2004. Digitalizirano bojišče. Bilten slovenske vojske december $2004-6(1)$. Ljubljana: GŠSV, str. 83-104.

7. Prezelj, I., Goričar, M., Cimprič, B., 2003. Vloga C4I sistemov v sodobnih oboroženih silah. Poljče: Višji štabni tečaj.

8. Sailers, B., 2000. Fire support digitization. http://www.dtic.mil/ndia/ cannon /sailers.pdf, 24. 3. 2010.

9. AFDVA, 2009. Vuurregeling bij de veldartillerie. http://www.4lafdva. net/Vuurregeling. htm, 9. 4. 2009.

10. Armed Forces International, 2008. HEROS 2/1. http://www.armedforces-int.com/ categories/mobile-command-systems/heros-command-control-information-systemmultinational.asp, 17. 3. 2010.

11. ESG, 2009. TARANIS Modulares taktisches Einsatzführungssystem. http://www.esg.de/ leistungen/itk/entwicklung/TARANIS.html, 12. 3. 2009.

12. Jane's, 2008. AUTOKO 90 (Germany) Systems. http://www.janes. com/articles/JanesMilitary-Communications/AUTOKO-90-Germany.html, 22. 4. 2010.

13. Jane's, 2008. Artillery Tactical Automatic Fire System (ATAFS) Italy, Command information systems - Land. http://www.janes.com/extracts lextract/jc4i/jc4i0062.html, 26. 4. 2009.

14. Jane's, 2006. C4I systems edition 2006-2007. Coulsdon: Jane's Information Group.

15. Jane's, 2009. ATLAS automated field artillery fire support system (France), Command information systems - Land. http://www. janes.com/articles/Janes-C4I-Systems/ATLASautomated-field-artillery-fire-support-system-France.html, 23. 4. 2010.

16. Systematic, 2007. Systematic SitaWare-Command and Control. http:// www.systematic. com/business + areas/defence/products/command+and+control, 17. 4. 2010.

17. Systematic, 2008. Systematic SitaWare Battle Management. http://www .systematic.com/ businessareas/defence/products/command+and+control/sitaware+battle+management, 17. 4. 2010.

18. U.S. Army Quarter Master Center and School, 2009. Organization. http://www.guarter master,army.mill, 19. 4. 2010. 